\title{
A Comparison of Three Methods for the Detection of Circulating Tumor Cells in Patients with Early and Metastatic Breast Cancer
}

\author{
Eleni Politaki ${ }^{a}$ Sofia Agelakia,b Stella Apostolaki ${ }^{a}$ Dora Hatzidakic \\ Areti Strati $^{d}$ Filippos Koinis $^{\mathrm{b}} \quad$ Maria Perraki $^{\mathrm{a}} \quad$ Georgia Saloustrou $^{\mathrm{a}}$ \\ Giannis Stoupis $^{b} \quad$ Galatea Kallergi $^{a} \quad$ Maria Spiliotaki ${ }^{a}$ Tereza Skaltsi ${ }^{c}$ \\ Evi Lianidou ${ }^{d}$ Vassilis Georgoulias ${ }^{c}$ Dimitrios Mavroudis ${ }^{a, b}$ \\ aLaboratory of Translational Oncology, School of Medicine, University of Crete, Heraklion, Crete, \\ ${ }^{b}$ Department of Medical Oncology, University General Hospital of Heraklion, Crete, ${ }^{c}$ Hellenic Oncology \\ Research Group (HORG), 55 Lombardou Street, Athens, 'Analysis of Circulating Tumor Cells Lab, \\ Laboratory of Analytical Chemistry, Department of Chemistry, University of Athens, Greece
}

\section{Key Words}

Circulating Tumor Cells - Breast Cancer - Cell Search System - Real Time RT-qPCR • Immunofluorescence

\begin{abstract}
Background: We directly compared CTC detection rates and prognostic significance, using three different methods in patients with breast cancer (BC). Methods: Early $(n=200)$ and metastatic $(n=164)$ patients were evaluated before initiating adjuvant or first-line chemotherapy, using the CellSearch ${ }^{\mathrm{TM}}$ System, an RT-qPCR for CK-19 mRNA detection and by double immunofluorescence (IF) microscopy using A45-B/B3 and CD45 antibodies. Results: Using the CellSearch ${ }^{\mathrm{TM}}$ System, $37 \%$ and $16.5 \%$ of early BC patients were CTC-positive (at $\geq 1$ and $\geq 2 \mathrm{CTCs} / 23 \mathrm{ml}$ of blood), $18.0 \%$ by RT-qPCR and $16.9 \%$ by IF; no agreement was observed between methods. By the CellSearch ${ }^{\mathrm{TM}} 34.8 \%$ and $53.7 \%$ (at $\geq 5$ and $\geq 2$ CTCs/7.5 $\mathrm{ml}$ ) of metastatic patients were CTC-positive, $37.8 \%$ by RT-qPCR and $28.5 \%$ by IF. A significant agreement existed only between the CellSearch ${ }^{\mathrm{TM}}$ and RT-qPCR. In $60.8 \%$ of cases, differential EpCAM and CK-19 expression on CTCs by IF could explain the discrepancies between the CellSearch ${ }^{\mathrm{TM}}$ and RT-qPCR. CTC-positivity by either method was associated with decreased overall survival in metastatic patients. Conclusion: A significant concordance was observed between the CellSearch ${ }^{\mathrm{TM}}$ and RT-qPCR in metastatic but not in early BC. Discordant results could be explained in part by CTC heterogeneity. CTC detection by all methods evaluated had prognostic relevance in metastatic patients.
\end{abstract}




\section{Cellular Physiology Cell Physiol Biochem 2017;44:594-606 \\ \begin{tabular}{ll|l} 
DOI: 10.1159/000485115 & $\begin{array}{l}\text { O } 2017 \text { The Author(s). Published by S. Karger AG, Basel } \\
\text { wwww.karger.com/cpb }\end{array}$ \\
\hline and Biochemished online: November 20, 201
\end{tabular}}

\section{Introduction}

Breast cancer is the second leading cause of cancer death in women exceeded only by lung cancer [1]. In breast cancer, dissemination of cancer cells with metastatic potential from the primary tumor through the blood or the lymphatics occurs early in the course of disease and is considered the main cause of subsequent disease-related death [2]. There is substantial evidence that the detection of circulating tumor cells (CTCs) in patients with early or metastatic breast cancer is associated with unfavourable prognosis, lack of treatment efficacy and tumor progression [3-9]. Thus, the detection of CTCs prior to and/ or during therapy has gained considerable interest, since peripheral blood sampling is easy and can be repeated as needed. However, other studies failed to support the prognostic and predictive value of CTCs in breast cancer [10-13]. These inconsistencies may be related to the sensitivity and specificity of the methods used for CTC isolation and detection. On the other hand, highly sensitive and specific assays have been developed to detect circulating tumor DNA (ctDNA) carrying tumor specific alterations in patients with cancer [14]. The potential of ctDNA analyses to detect occult minimal residual disease and to predict clinical response to therapy and survival in breast cancer is being actively explored $[15,16]$.

CTC assays rely on a combination of different enrichment and detection steps in order to enhance their sensitivity and specificity [17]. The technical variability of these assays, the heterogeneity of CTCs, as well as the possible treatment-induced alterations on marker expression, posed significant challenges as to which is the optimal detection method.

The CellSearch ${ }^{\mathrm{TM}}$ System, the only method clinically validated and cleared for use in patients with metastatic breast, prostate and colorectal cancer, uses ferrofluid nanoparticles with antibodies against the epithelial cell adhesion molecule (EpCAM), thus separating epithelial cells from the majority of blood cells. Further staining of cells with specific antibodies for cytokeratins (CK), the common leukocyte antigen (CD45), nuclear dye (DAPI) and visualization under microscopy enables the identification of CTCs [3]. The detection of CTCs by the use of CellSearch ${ }^{\mathrm{TM}}$, at any time-point during the course of therapy, was predictive of the progression-free and overall survival of patients with metastatic breast, prostate or colorectal cancer [18].

Our group has developed a Real-Time quantitative Polymerase Chain Reaction (RTqPCR) assay for the detection of CK19-mRNA in the peripheral blood mononuclear cells (PBMCs) compartment after Ficoll isolation [19]. The presence of CK19 mRNA-positive CTCs has been associated with an unfavourable clinical outcome in patients with either early or metastatic breast cancer. Specifically, the detection of CK19 mRNA-positive cells either before the initiation or after the completion of adjuvant chemotherapy as well as during follow-up, was predictive of poor clinical outcome in patients with early stage breast cancer $[7,8,20]$ . In the metastatic setting, the presence of CK19 mRNA-positive cells before the initiation of front-line chemotherapy identifies a group of patients with dismal prognosis [21].

One limitation of PCR-based assays is that they provide the number of target transcripts according to the actual number of CTCs present in a sample [17] and do not allow the morphologic evaluation of cells. To overcome this limitation, cell-based assays have also been used for the detection and characterization of CTCs. We developed a method of multifluorescent immunostaining of PBMCs spun on glass slides to identify the markers of interest on tumor cells [22-24]. However, this assay has not as yet been evaluated in comparison to other methods for its performance to detect CTCs.

The aim of the present study was to compare the three assays for the detection of CTCs in patients with early and metastatic breast cancer; the RT-qPCR for CK19 mRNA [19], the immunofluorescent (IF) assay and the CellSearch ${ }^{\mathrm{TM}}$ platform regarding their relative efficiency in detecting CTCs. We also assessed their performance in predicting patients' clinical outcome. 


\section{Cellular Physiology Cell Physiol Biochem 2017;44:594-606 \begin{tabular}{l|l} 
and Biochemistry Published online: November 20, 2017 & $\begin{array}{l}\text { (C) } 2017 \text { The Author(s). Published by S. Karger AG, Basel } \\
\text { www.karger.com/cpb }\end{array}$
\end{tabular} \\ Politaki et al.: Comparison of Three Methods for the Detection of CTCs in Breast Cancer}

\section{Materials and Methods}

\section{Patients}

From 2007 to 2010, patients with histologically confirmed early or metastatic breast cancer, treated at the Department of Medical Oncology of the University Hospital of Heraklion and the First Department of Medical Oncology of the IASO General Hospital, Athens, were prospectively tested for the presence of CTCs before the initiation of adjuvant or first-line chemotherapy, respectively. Only patients aged $\geq 18$ years, without a history of a second malignancy within the previous 5 years, except of a skin non-melanoma malignancy or an in situ cervical cancer, were included in the present study. In addition, 26 healthy female blood donors were enrolled as a control group. All patients and healthy donors enrolled in this study gave written informed consent in order to participate and the study was approved by the Ethical and Scientific Committee of our Institution.

\section{Sample collection}

Twenty millilitres (ml) of peripheral blood was collected in EDTA tubes for CK19 mRNA and immunofluorescent analysis [19]. To avoid blood contamination by epithelial cells of the skin, all blood samples were obtained after the first $5 \mathrm{ml}$ of blood was discarded.

Blood was diluted with equal volume of $0.9 \% \mathrm{NaCl}$ and PBMCs were obtained by gradient density centrifugation using Ficoll Hypaque (Sigma Chemical Company, St. Louis, MO) at $670 \mathrm{~g}$ for $30 \mathrm{~min}$ at $4^{\circ} \mathrm{C}$. The interface cells were removed, washed twice with $40 \mathrm{~mL}$ of sterile PBS at $529 \mathrm{~g}$ for $10 \mathrm{~min}$ and resuspended in $10 \mathrm{~mL}$ of PBS. Cell pellets were kept at $-80^{\circ} \mathrm{C}$ until RNA extraction. In parallel, 500.000 PBMCs/slide were cytocentrifuged, air-dried and stored at $-80^{\circ} \mathrm{C}$, to be used in immunofluorescence experiments.

For the detection of CTCs by the CellSearch ${ }^{\mathrm{TM}}$ System, $7.5 \mathrm{ml}$ of blood was collected from patients with metastatic disease [3] and $23 \mathrm{ml}$ from patients with early disease [6]. Blood was drawn into CellSave Vacutainer tubes (Veridex LLC, JnJ, USA), which contained EDTA and an optimized cell preservative. In the case of healthy female controls, $7.5 \mathrm{ml}$ and $23 \mathrm{ml}$ of blood was collected in order to correspond to the blood volumes evaluated in the metastatic and adjuvant settings, respectively. Images obtained by the CellSearch System were reviewed by readers that had received the appropriate training in image interpretation for the definition of CTCs.

Total RNA isolation and cDNA synthesis

Total RNA isolation was performed by using Trizol reagent (Invitrogen, USA) according to the manufacturer's instructions. All preparation and handling steps of RNA took place in a laminar flow hood, under RNAse-free conditions. The isolated RNA was dissolved in RNA storage buffer (Ambion, USA) and stored at $-80^{\circ} \mathrm{C}$ until used [19]. RNA concentration was determined using Nanodrop Spectrophotometer ND1000. Reverse transcription of RNA was carried out with the SuperScript ${ }^{\text {TM }}$ III Platinum Two-Step RT-qPCR Kit (Invitrogen, USA).

\section{Detection of CTCs by RT-qPCR}

The real-time RT-qPCR assay for CK19 mRNA detection was performed as previously described. Briefly, the real-time RT-qPCR assay was performed in a total volume of $10 \mu \mathrm{L}$ in the LightCycler glass capillaries. For the PCR, $1 \mu \mathrm{L}$ of cDNA was placed into a $9 \mu \mathrm{L}$ reaction volume containing $1 \mu \mathrm{L}$ of the PCR Synthesis. Primers and Probes were provided by TIB MOLBIOL (Berlin, Germany). The analytical details (specificity, sensitivity, cut-off for positivity), the primers and probes used as well as the cycling protocol have been previously described [19].

RNA integrity was tested by PCR amplification of the PBGD housekeeping gene. Results are expressed as MCF-7 cell equivalents per $5 \mu \mathrm{g}$ of total-RNA, as determined by the LightCycler System software 3.1. The lower detection limit for positivity of the assay has been determined to be $\geq 0.6 \mathrm{MCF}-7$ cell equivalents $/ 5 \mu \mathrm{g}$ RNA for the patients' PBMCs.

Detection of CTCs by double and triple immunofluorescence (IF)

PBMC cytospins were fixed using cold aceton/methanol (9:1) for $20 \mathrm{~min}$ at room temperature and blocked with PBS/5\% FBS, $0.9 \mathrm{mM} \mathrm{CaCl}_{2}, 0.5 \mathrm{mM} \mathrm{MgCl}_{2}$ for $1 \mathrm{~h}$. Cells were incubated with an anti-CD45 (common leukocyte antigen) rabbit antibody (Santa Cruz, USA) for $1 \mathrm{~h}$ along with the corresponding 


\section{Cellular Physiology Cell Physiol Biochem 2017;44:594-606 \begin{tabular}{l|l} 
and Biochemistry Published 10.1159/000485115 & (c) 2017 The Author(s). Published by S. Karger AG, Basel \\
www.karger.com/cpb
\end{tabular} \\ Politaki et al.: Comparison of Three Methods for the Detection of CTCs in Breast Cancer}

Table 1. Reproducibility of the IF assay determined by cell spiking experiments; 10 and 100 MCF-7 cells were spiked into $1 \times 10^{6}$ PBMCs in triplicate and cytospins of 500.000 PBMCs were prepared. Two random cytospins of 500.000 PBMCs are evaluated for each concentration. CTC-positivity is defined as the presence of at least 1 CK-positive CTC $/ 10^{6}$ PBMCs. Results of 3 separate experiments are presented

\begin{tabular}{|c|c|c|c|}
\hline MCF-7 cells Spiked/ & \multicolumn{3}{|c|}{ CTC detection } \\
\hline & Cytospin & Cytospin & CTC-Positivity \\
\hline 10 & - & + & + \\
\hline 10 & - & + & + \\
\hline 10 & + & + & + \\
\hline 100 & + & + & + \\
\hline 100 & + & + & + \\
\hline 100 & + & + & + \\
\hline
\end{tabular}

secondary Alexa 555 anti-rabbit antibody (Molecular Probes, Invitrogen, USA) for $45 \mathrm{~min}$ followed by the A45-B/B3 mouse antibody (which recognizes the CK8/18 and CK19; Micromet, Germany) for $1 \mathrm{~h}$ along with the corresponding secondary fluorescein anti-mouse antibody for 45 min (Molecular Probes, Invitrogen, USA). Negative controls were set for the primary antibodies by omitting the corresponding primary antibody and adding the secondary immunoglobulin G (IgG) isotype antibody. 4',6-diamidino-2-phenylindole (DAPI) antifade reagent (Invitrogen, Carlsbad, CA, USA) was added to each sample for nuclear staining. Cytospins were evaluated by IF microscopy at 40x magnification using the Leica DM 2500 microscope. CK-positive cells were determined as CTCs if they presented no staining for CD45 and met the cytomorphological criteria proposed by Meng et al [25]. (i.e DAPI-positive, high nuclear/cytoplasmic ratio and size larger than white blood cells). For each patient, two slides were analyzed and results are expressed as CK(+) CTCs $/ 10^{6}$ PBMCs. The detection of at least one CK-positive CTC $/ 10^{6}$ PBMCs was required for the definition of CTCpositivity.

To determine the reproducibility of the IF assay for CTC detection, 10 and 100 MCF-7 cells $/ 10^{6}$ PBMCs were spiked into $1 \times 10^{6}$ normal donor PBMCs in triplicate and cytospins of 500.000 PBMCs were prepared. Two random cytospins for each concentration were stained with the CD45/A45-B/B3 antibodies. The detection of at least 1 CK-positive CTC/10 $10^{6}$ PBCs was required for the definition of CTC-positivity. The experiment was repeated three separate times and results are presented in Table 1.

In order to investigate the discrepancies observed by CellSearch ${ }^{\mathrm{TM}}$ and RT-qPCR in patients, triple IF experiments for the detection of EpCAM, CD45 and CK19, were carried out in PBMC cytospins. PBMC cytospins, prepared as described above, were incubated with the CD45 mouse monoclonal antibody (Dako, Denmark) along with the corresponding secondary anti-mouse antibody labelled with Alexa 633 [Far Red] fluorochrome (Invitrogen, USA) for $45 \mathrm{~min}$, followed by EpCAM rabbit antibody (Abcam, Cambridge, UK) for $1 \mathrm{~h}$, along with the corresponding secondary anti-rabbit antibody labelled with Alexa 555 fluorochrome for 45 min (Invitrogen, USA) and lastly with an anti-CK19 mouse fluorescein isothiocyanate (FITC)-conjugated antibody (Abcam, Cambridge, UK) for $1 \mathrm{~h}$. Finally, CTCs were detected by immunofluorescence using the Ariol System. (Molecular Devices, New Milton, UK). For each patient, two slides were tested and results were expressed as CTCs $/ 10^{6}$ PBMCs.

Isolation and Enumeration of CTCs by the CellSearch ${ }^{T M}$

The CellSearch ${ }^{\mathrm{TM}}$ System (Veridex, JnJ, USA) was used for the isolation and enumeration of CTCs in peripheral blood. The CellSearch ${ }^{\mathrm{TM}}$ Circulating Tumor Cell Kit (Veridex Warren, NJ) was applied for CTC enrichment and enumeration. For the purpose of this analysis, two cut-off values were used to determine CTC positivity in samples; 1 or more and 2 or more CTCs $/ 23 \mathrm{ml}$ of blood were used in the adjuvant setting, whereas in the metastatic setting the respective cut-offs were 2 or more and 5 or more CTCs/7.5 ml of blood.

\section{Statistical design and analysis}

The aim of this study was to compare the three assays [RT-qPCR for CK19 mRNA, immunofluorescence (IF) and CellSearch ${ }^{\mathrm{TM}}$ ] for the detection of CTCs in patients with early and metastatic breast cancer and to assess their performance in predicting patients' clinical outcome. 


\section{Cellular Physiology \\ \begin{tabular}{ll|l} 
and Biochemistry & $\begin{array}{l}\text { DOI: 10.1159/000485115 } \\
\text { Published onlıne: November 20, } 2017\end{array}$ & $\begin{array}{l}\text { C } 2017 \text { The Author(s). Published by S. Karger AG, Basel } \\
\text { www.karger.com/cpb }\end{array}$ \\
\hline Politaki et al. Comparison of Three Methods for the Detection of CTCs in Breast Cancer
\end{tabular}}

Summary tables (descriptive statistics and/or frequency tables) are provided for all baseline variables and efficacy variables, as appropriate. Continuous variables are summarized with descriptive statistics (n, mean, standard deviation, range, and median). Disease Free Survival (DFS) in the adjuvant setting was defined as the time from study entry until the date of first evidence of clinical or radiological disease recurrence or death from any cause. Progression Free Survival (PFS) in metastatic patients was defined as the time from study entry until clinical or radiological disease relapse or death from any cause. Overall Survival (OS) was measured from the date of study entry until the date of death from any cause or the date of last follow-up.

Qualitative factors were compared by Pearson's Chi-square test or Fisher's exact test whenever appropriate. Differences in positivity rates were assessed using the McNemar test. In addition, the Kappa test was used in all cases to evaluate the agreement between the three molecular methods. The normality of continuous variables was tested using the Kolmogorov-Smirnov test and the Spearman's exact test was used to evaluate the correlation between the three molecular methods. DFS, PFS and OS were estimated using the Kaplan-Meier analysis and the comparisons were computed with the log-rank test.

All statistical tests were two-sided, and p-values $<0.05$ were considered statistically significant. Data were analyzed using the SPSS statistical software, version 22.0 (SPSS Inc., Chicago, IL, USA).

\section{Results}

Patients

Two-hundred consecutive patients with early stage and 164 with metastatic breast cancer were evaluated for CTC detection by the use of RT-qPCR for CK19 mRNA and the CellSearch ${ }^{\mathrm{TM}}$ System before the initiation of adjuvant and first-line chemotherapy, respectively. Patient characteristics are depicted in Table 2 (A, B). In 178 of these patients with early and in 105 with metastatic disease, blood samples were also evaluated by the use of IF.

Detection of epithelial cells in the peripheral blood of healthy women

No CK19 mRNA-positive cells were detected in the peripheral blood of 26 healthy female blood donors. Using immunostaining and IF microscopy, 1 out of 26 healthy females tested positive, harboring 1 cell $/ 10^{6}$ PBMCs. In addition, using the CellSearch ${ }^{\mathrm{TM}}$ platform, one and two healthy controls had 1 cell $/ 7.5 \mathrm{~mL}$ and 1 cell/23mL of blood, respectively.

\section{Detection of CTCs in early breast cancer}

Using the real time RT-qPCR assay, 36 of $200(18 \%)$ patients with early breast cancer, were CTC-positive at baseline. Using the CellSearch ${ }^{\mathrm{TM}}$ system 74 (37\%) and 33 (16.5\%) of patients had detectable CTCs (cut-offs $\geq 1$ and $\geq 2$, respectively). Among 178 patients evaluated by IF microscopy, 30 (16.9\%) had CK-positive CTCs.

At the cut-off of $\geq 1 \mathrm{CTCs} / 23 \mathrm{ml}$ of blood for the CellSearch ${ }^{\mathrm{TM}}$ system, the CTC-positivity rate with at least one method was $38.5 \%$. However, CTC-positivity according to whether a specific sample from a patient was reported as positive with all three methods was only $2.5 \%$.

Differences in positivity between methods were compared using the Mc Nemar test. Patients were more likely to be CTC-positive using the CellSearch ${ }^{\mathrm{TM}}$ (at $\geq 1$ ) than real-time RT-qPCR $(37 \%$ vs $18.0 \%, P<0.001)$ or IF $(37 \%$ vs $16.9 \%, P<0.001)$. The overall concordance between RT-qPCR and CellSearch ${ }^{\mathrm{TM}}$, defined as the case in which the sample from a patient was reported as positive or negative by both methods, was $62 \%$ and $73.5 \%$ for the cut-offs of $\geq 1$ and $\geq 2$, respectively ( $\kappa=0.088, p=0.161$ and $\kappa=0.072, p=0.307, \kappa$ - test). Similarly, the overall agreement between the IF and CellSearch ${ }^{\mathrm{TM}}$ was $61.8 \%$ and $71.9 \%$ for the cut-offs of $\geq 1$ and $\geq 2$, respectively ( $\kappa=0.078, p=0.233$ and $\kappa=<0, p=0.976, \kappa$ - test). The agreement between the IF and RT-qPCR was 73\% ( $\kappa=0.086, p=0.248, \kappa$ - test). The concordance rates between methods are included in Table 3A. 
Table 2. Patient characteristics. A. Early Breast Cancer, B. Metastatic Breast Cancer

\begin{tabular}{|c|c|c|c|c|c|}
\hline $\begin{array}{l}\text { A } \\
\text { No of Patients }\end{array}$ & $\mathrm{N}=172$ & $\%$ & $\begin{array}{l}\text { B } \\
\text { No of Patients }\end{array}$ & $\mathrm{N}=137$ & $\%$ \\
\hline Age & & & Age & & \\
\hline Median (min -max) & $50(25-81)$ & & Median (min -max) & $61.0(23-82)$ & \\
\hline Menopausal status & & & $\begin{array}{l}\text { Menopausal status } \\
\text { Premenopausal }\end{array}$ & 34 & 24.8 \\
\hline Premenopausal & 64 & 37.2 & Postmenopausal & 103 & 75.2 \\
\hline Postmenopausal & 108 & 62.8 & & & \\
\hline Type of Surgery & & & Primary Breast Cancer at diagnosis & & \\
\hline Breast conserving surgery & 123 & 71.5 & $\begin{array}{l}\text { Yes } \\
\text { No }\end{array}$ & $\begin{array}{l}91 \\
46\end{array}$ & 66.4 \\
\hline Mastectomy & 49 & 28.5 & & & \\
\hline Histology & & & Prior Adjuvant therapy & & \\
\hline Ductal & 153 & 89.0 & Chemotherapy & 81 & 59.1 \\
\hline Lobular & 11 & 6.4 & $\begin{array}{l}\text { Hormone therapy only } \\
\text { Unknown }\end{array}$ & $\begin{array}{l}7 \\
3\end{array}$ & $\begin{array}{l}5.1 \\
2.2\end{array}$ \\
\hline Mixed & 6 & 3.5 & & & \\
\hline Mucinous & 2 & 1.2 & Hormone Receptor Status & & \\
\hline Tumor size & & & ER and/or PR positive & 103 & 75.2 \\
\hline$\leq 2 \mathrm{~cm}$ & 70 & 40.7 & ER and PR negative & 30 & 21.9 \\
\hline $2-5 \mathrm{~cm}$ & 85 & 49.4 & Unknown & 4 & 2.9 \\
\hline$\geq 5 \mathrm{~cm}$ & 17 & 9.9 & Her2 & & \\
\hline Lymph Nodes & & & Negative & 110 & 80.3 \\
\hline 0 & 49 & 28.5 & Positive & 22 & 16.1 \\
\hline $1-3$ & 82 & 47.7 & Unknown & 5 & 3.6 \\
\hline$\geq 4$ & 41 & 23.8 & Disease status & & \\
\hline Grade & & & Visceral & 93 & 67.9 \\
\hline I & 8 & 4.7 & Non Visceral & 44 & 32.1 \\
\hline II & 73 & 42.4 & & & \\
\hline III & 83 & 48.3 & $\begin{array}{l}\text { Best response } \\
\text { CR+PR }\end{array}$ & 73 & 53.3 \\
\hline Lobular & 6 & 3.5 & $S D+P D$ & 64 & 46.7 \\
\hline Unknown & 2 & 1.2 & & & \\
\hline Hormone Receptor Status & & & Relapses & & \\
\hline ER and/or PR positive & 132 & 76.7 & Yes & 112 & 81.8 \\
\hline ER and PR negative & 40 & 23.3 & No & 25 & 18.2 \\
\hline Her2 & & & Vital Status & & \\
\hline Negative & 134 & 77.9 & Dead & 74 & 54.0 \\
\hline Positive & 38 & 22.1 & Alive & 63 & 46.0 \\
\hline Relapse & & & & & \\
\hline Yes & 32 & 18.6 & & & \\
\hline No & 140 & 81.4 & & & \\
\hline Vital Status & & & & & \\
\hline Dead & 19 & 11.0 & & & \\
\hline Alive & 153 & 89.0 & & & \\
\hline
\end{tabular}

Table 3. Concordances between the three CTC detection methods. A. Early Breast Cancer, B. Metastatic Breast Cancer

\begin{tabular}{lcccc}
\hline A & K coefficient & p-value & Degree of agreement & Agreement (\%) \\
\hline Cell search (cut-off $\geq 1$ ) vs RT-qPCR & 0.088 & 0.161 & Poor & 62 \\
Cell search (cut-off $\geq$ 1) vs IF & 0.078 & 0.233 & Poor & 61.8 \\
Cell search (cut-off $\geq 2$ ) vs RT-qPCR & 0.072 & 0.307 & Poor & 73.5 \\
Cell search (cut-off $\geq$ 2) vs IF & 0 & 0.976 & None & 71.9 \\
RT-qPCR vs IF & 0.086 & 0.248 & Poor & 73.0 \\
B & K coefficient & p-value & Degree of agreement & Agreement (\%) \\
\hline Cell search (cut-off $\geq 2$ ) vs RT-qPCR & 0.281 & $<0.001$ & Fair & 63.4 \\
Cell search (cut-off $\geq 2$ ) vs IF & 0.041 & 0.619 & Poor & 49.5 \\
Cell search (cut-off $\geq 5$ ) vs RT-qPCR & 0.302 & $<0.001$ & Fair & 67.7 \\
Cell search (cut-off $\geq 5$ ) vs IF & 0.049 & 0.607 & Poor & 58.1 \\
RT-qPCR vs IF & 0.011 & 0.902 & Poor & 49.5 \\
\hline
\end{tabular}


Fig. 1. Expression of cytokeratin 19, EpCAM and CD45 in CTCs of patients with breast cancer. (A) Representative image of two CTCs staining positive for cytokeratin (CK) 19 and EpCAM along with PBMCs. (B) Representative image of a CTC staining positive for CK19. (C) Representative image of a CTC staining positive for EpCAM. Cytospins were triple stained, with an anti-CD45 mouse antibody along with the corresponding secondary anti-mouse antibody labelled with Alexa 633 (red) fluorochrome followed by EpCAM rabbit antibody, along with the corresponding secondary antirabbit antibody labelled with Alexa 555 (orange) fluorochrome and with an anti-CK19 mouse fluorescein isothiocyanate (FITC)conjugated antibody (green). Cell nuclei were stained with DAPI

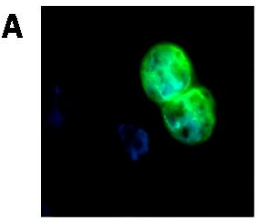

CK19 positive

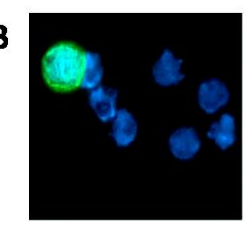

CK19 positive

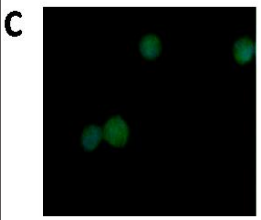

CK19 negative

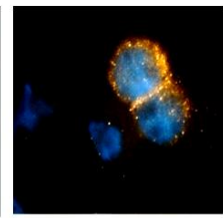

EpCAM positive

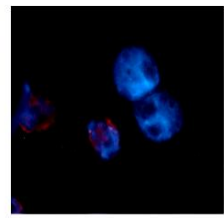

CD45 negative

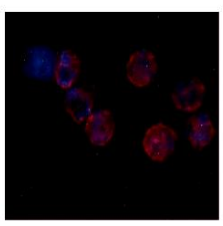

CD45 negative

EpCAM negative

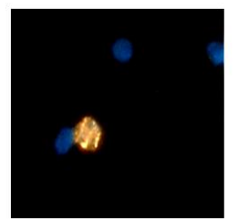

EpCAM positive

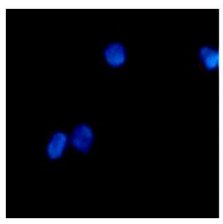

CD45 negative

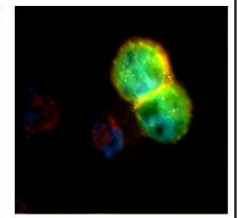

Overlay

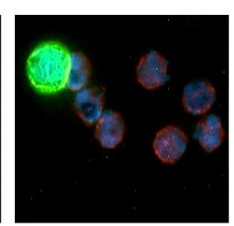

Overlay

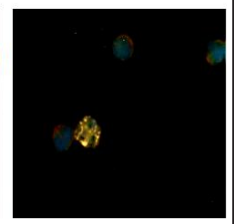

Overlay

(blue). Images were taken by ARIOL system (X60). ARIOL system, automated image analysis system; CTCs, circulating tumor cells.

\section{Detection of CTCs in metastatic breast cancer}

Using RT-qPCR, 62 (37.8\%) of 164 patients had detectable CK19 mRNA-positive CTCs. Using the CellSearch ${ }^{\mathrm{TM}}$ system, 57 (34.8\%) patients had $\geq 5$ and $88(53.7 \%)$ had $\geq 2$ CTCs $/ 7.5$ $\mathrm{ml}$ of blood. Among 105 patients evaluated by IF, CTCs could be detected in $30(28.6 \%)$ of them. At the cut-off of $\geq 5 \mathrm{CTCs} / 7.5 \mathrm{ml}$ of blood for the CellSearch ${ }^{\mathrm{TM}}$ system, $6.1 \%$ of patients had detectable CTCs by all three and $64 \%$ with at least one method.

A significant difference in positivity was observed among the CellSearch ${ }^{\mathrm{TM}}$ (cut-off $\geq 2$ ), the RT-qPCR and IF. Patients with MBC were more likely to be CTC-positive using the CellSearch $^{\mathrm{TM}}$ system compared to real-time RT-qPCR (53.7 vs 37.8\%, $P=0.001$, McNemar test) or the IF test (56.2\% vs $28.6 \%, P<0.001$, McNemar test). In addition, a significant difference in positivity was recorded using the RT-qPCR and IF ( $52.4 \%$ vs $28.6 \%, P=0.001$, McNemar test).

The overall agreement between RT-qPCR and CellSearch ${ }^{\mathrm{TM}}$ was $63.4 \%$ and $67.7 \%$ ( $\kappa=0.281, p<0.001$ and $\kappa=0.302, p<0.001, \kappa$ - test) at $\geq 2$ and $\geq 5$ CTCs, respectively. Regarding the comparison between CellSearch ${ }^{\mathrm{TM}}$ and IF the agreement was $49.5 \%(\kappa=0.041, p=0.619$, $\kappa$ - test $)$ and $58.1 \%(\kappa=0.049, p=0.607, \kappa$ - test $)$ at $\geq 2$ and $\geq 5$ CTCs, respectively whereas, the agreement between RT-qPCR and IF was $49.5 \%$ ( $\kappa=0.011, p=0.902, \kappa$ - test). The concordance rates between methods in metastatic breast cancer are included in Table 3B.

\section{Expression of EpCAM and CK19 on CTCs of patients with breast cancer}

To investigate the possible contribution of CTC heterogeneity as the cause of discrepancies observed between the 3 methods, triple IF experiments for the detection of EpCAM, CD45 and CK-19 were performed in PBMC cytospins obtained from 72 patients presenting discordance in the detection of CTCs by the CellSearch ${ }^{\mathrm{TM}}$ system and RT-qPCR (Fig. $1 \mathrm{~A}, \mathrm{~B}, \mathrm{C}$ ). Using IF, CTCs were detected in $23(31.94 \%)$ of 72 patients. In 7 of 23 patients, CTCs were detected with RT-qPCR only [(CellSearch ${ }^{\mathrm{TM}}(-) /$ RT-qPCR $\left.(+)\right]$ and in 16 with CellSearch ${ }^{\mathrm{TM}}$ only [CellSearch ${ }^{\mathrm{TM}}$ $(+) /$ RT-qPCR(-)]. Among a total of 747 CTCs detected by IF, 34\% expressed both CK19 and 
Table 4. Characterization of CK19 and EpCAM expression on CTCs by the use of IF microscopy in cases determined as discordant for CTC-positivity by the RT-QPCR and the CellSearch $^{\mathrm{TM}}$

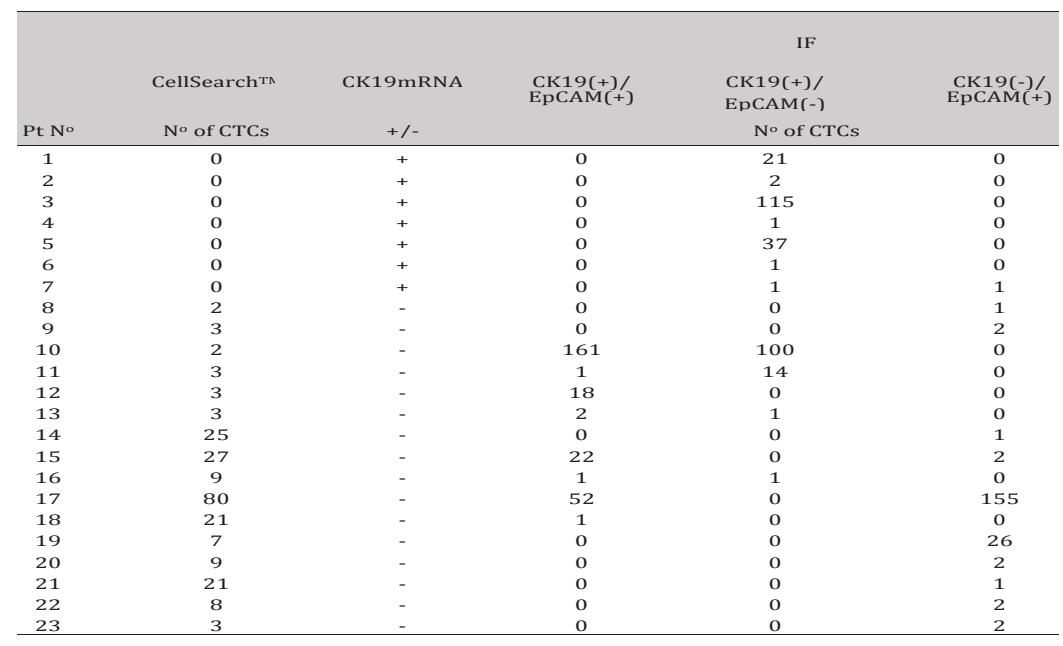

FIG. 2. Kaplan-Meier plots of survival. (A) progression - free survival and (B) overall survival, according to the absence (-) or the presence $(+)$ of CTCs in the peripheral blood in patients with metastatic breast cancer, using the CellSearch System (at $\geq 5$ CTCs), RTPCR and IF. p-values refer to log-rank tests

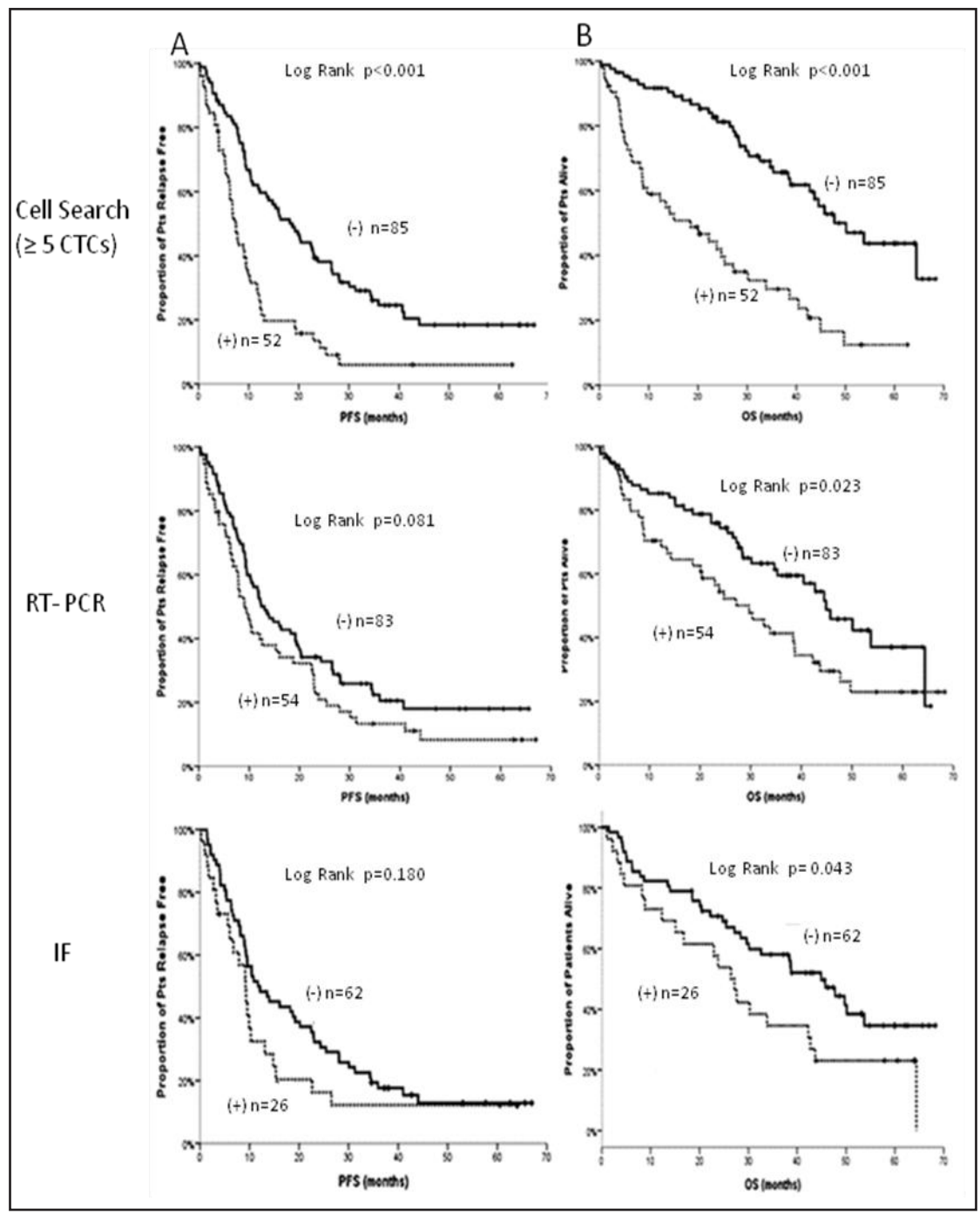

EpCAM [CK19(+)/EpCAM(+)], 26\% were CK19(-)/EpCAM(+) and 39\% CK19(+)/EpCAM(-). The different immunophenotypes of CTCs observed in each patient are depicted in Table 4.

As shown in Table 4, in 6 out of 7 patients determined as CTC-positive by RT-qPCR only (\# 1-6), exclusively CK19(+)/EpCAM(-) CTCs, not expected to be captured by the CellSearch ${ }^{\mathrm{TM}}$ 
system due to lack of EpCAM expression, were detected, whereas in one case (\# 7), CK19(+)/ EpCAM(-) along with CK19(-)/EpCAM(+) CTCs were observed. In the group of discordant cases classified as CTC-positive by CellSearch ${ }^{\mathrm{TM}}$ only, $50 \%$ of patients had exclusively $\operatorname{EpCAM}(+) / C K 19(-)$ CTCs (patients \# 8, 9, 14, 19, 20, 21, 22, 23), thus explaining the negative result using the RT-qPCR for CK19 mRNA, 13\% $(\# 12,18)$ had exclusively CK19(+)/EpCAM(+) CTCs, whereas the remaining patients presented variability in the CTC phenotypes.

\section{Prognostic relevance of CTC detection by the three methods}

A total of 172 patients with early breast cancer with available follow up data were evaluated for the prognostic significance of CTC detection. CTCs were identified in $30.8 \%$ and $12.8 \%$ (cut off $\geq 1$ and $\geq 2$ CTCs, respectively) of these patients using the CellSearch ${ }^{\mathrm{TM}}$ system, in $18.6 \%$ by RT-qPCR and in $19.2 \%$ by IF. After a median follow up period of 74.8 months (range, 2.1-100.7), 32 (18.6\%) patients had experienced disease recurrence and 18 $(11.0 \%)$ had died. There was no difference in the number of recurrences or deaths among CTC-positive and CTC-negative patients, regardless of the detection method. At the time of analysis, the median disease-free survival and overall survival had not yet been reached.

The prognostic value of CTC detection was also evaluated in 137 metastatic patients. CTCs were detected in $52.6 \%$ and $38 \%$ of patients with the CellSearch ${ }^{\mathrm{TM}}$ system (at $\geq 2$ and $\geq 5$ CTCs cut-offs, respectively), in $39.4 \%$ with RT-qPCR and in $29.5 \%$ with IF. After a median follow-up time of 45.6 months (range 0.3 - 68.3), the median PFS in CTC-positive versus CTCnegative patients determined using the CellSearch ${ }^{\mathrm{TM}}$ at $\geq 2$ and $\geq 5$ CTCs, was 7.9 compared to 22.4 months $(\mathrm{p}<0.001)$ and 7.4 compared to 18.7 months $(\mathrm{p}<0.001)$, respectively. On the other hand, no statistically significant difference in the median PFS was detected for patients with or without CTCs according to CK19 mRNA detection ( $\mathrm{p}=0.081)$ or IF-positivity $(\mathrm{p}=0.180)$. The median overall survival in CTC-positive versus CTC-negative patients using the CellSearch $^{\mathrm{TM}}$ at $\geq 2$ and $\geq 5$ CTCs was 23.8 compared to 53.7 months $(\mathrm{p}<0.001)$ and 18.5 compared to 47.7 months ( $\mathrm{p}<0.001)$, respectively. Moreover, CTC-positivity determined by either RT-qPCR or IF, was also associated with significantly reduced median overall survival (29.7 vs 44.9 months, $\mathrm{p}=0.023$ and 26.5 vs 44.9 months, $\mathrm{p}=0.043$, respectively). Representative survival curves are presented in Fig. 2.

\section{Discussion}

Different CTC detection assays exist that vary considerably in the methods and markers used for CTC isolation and visualisation, the volume of blood analyzed as well as the definition of positivity. In addition, given the significant heterogeneity of CTCs, it is not clear whether these methods detect all CTCs or even the same subpopulations of CTCs, since epithelialto-mesenchymal transition, a common feature of CTCs, may preclude CTC identification by the use of epithelial markers [26-28]. As a consequence, comparison between studies is difficult and therefore, despite the fact that in multiple reports the presence of CTCs has been correlated with patients' outcome, CTCs have not as yet been approved for widespread clinical use. CellSearch ${ }^{\mathrm{TM}}$, an automated system for CTC detection and enumeration, is the only one that has gained regulatory approval for use in patients with metastatic breast, prostate and colorectal cancer. Although the prognostic significance of CTCs in early breast cancer has been shown in several studies $[4,6-8,20]$, there is currently no generally acceptable method for CTC isolation and detection in this setting.

In the present study we aimed to compare three different methods for the detection of CTCs in patients with early and metastatic breast cancer: i) the automated CellSearch ${ }^{\mathrm{TM}}$ system ii) an in-house developed real-time RT-qPCR for the detection of CK19 mRNA in peripheral blood and iii) an immunofluorescent cytokeratin-based method. The main features of these assays are summarized in Table 5. All three different methods employ the detection of cytokeratins as marker of epithelial cells. However, it should be mentioned here that the immunocytochemical staining of bone marrow aspirates for a broad spectrum 
Table 5. Main characteristics of the three assays for CTC detection; CellSearch System, RT-PCR for CK-19 mRNA and Immunofluorescence analysis

\begin{tabular}{|c|c|c|c|c|}
\hline Assay & Blood volume & Enrichment method & Detection method & Cut-off \\
\hline Cell Search & $\begin{array}{c}7.5 \mathrm{ml} / 23 \mathrm{ml} \\
\text { (metastatic / adjuvant } \\
\text { disease) }\end{array}$ & $\begin{array}{l}\text { Ferrofluids containing EpCAM } \\
\text { antibodies }\end{array}$ & $\begin{array}{c}\text { Immunodetection of } \\
\text { CK 8, 18, } 19 \text { and DAPI } \\
\text { staining, lack of CD } 45 \\
\text { detection }\end{array}$ & $\begin{array}{l}\geq 2, \geq 5 \mathrm{CTCs} / 7.5 \mathrm{ML} \\
\geq 1, \geq 2 \mathrm{CTCs} / 23 \mathrm{ML}\end{array}$ \\
\hline RT-PCR & $20 \mathrm{ml}$ & $\begin{array}{l}\text { Manually operated density } \\
\text { gradient centrifugation }\end{array}$ & $\begin{array}{c}\text { RT-PCR for CK-19 } \\
\text { mRNA } \\
\text { Immunodetection of }\end{array}$ & 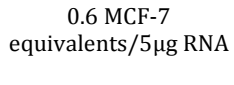 \\
\hline Immunofluorescence & $10^{6} \mathrm{PBMCs}$ & $\begin{array}{l}\text { Manually operated density } \\
\text { gradient centrifugation }\end{array}$ & $\begin{array}{l}\text { CK 8, 18, } 19 \text { and DAPI } \\
\text { staining, lack of CD } 45 \\
\text { detection }\end{array}$ & $\geq 1 \mathrm{CTCs} / 10^{6} \mathrm{PBMCs}$ \\
\hline
\end{tabular}

of cytokeratins in patients with breast cancer, showed that the true positive rate for the detection of disseminated tumor cells was $52.6 \pm 11.5 \%$ [29].

Our results show a significant concordance for CTC detection between RT-qPCR for CK19 mRNA and the CellSearch ${ }^{\mathrm{TM}}$ system in the metastatic but not in the adjuvant setting. No agreement was found between the CellSearch ${ }^{\mathrm{TM}}$ system and IF, or the RT-qPCR for CK19 mRNA and IF, in either early or metastatic disease. It should be noted however that high numbers of negative events, especially in the early disease setting, were recorded by all three methods. Interestingly, CTC detection by either method was of prognostic relevance in metastatic patients.

In general, previous reports have demonstrated conflicting results regarding the agreement between different methods of CTC detection in metastatic patients. Thus, the comparison between the CellSearch ${ }^{\mathrm{TM}}$ system and AdnaTest Breast Cancer, a commercially available molecular method that includes cell isolation by an antibody-mix against EpCAM and MUC-1 linked to magnetic particles followed by real-time PCR for EpCAM, MUC-1 and HER2, revealed a significant agreement in metastatic disease [30]. However, in another study, when the CellSearch ${ }^{\mathrm{TM}}$ was compared with AdnaTest Breast Cancer and an in-house developed real-time RT-qPCR assay for CK19 and mammaglobin transcripts in metastatic patients, a substantial variation in CTC detection rates and a moderate concordance between methods was reported [31]. In addition, a comparison of two cell-based detection assays, the CellSearch $^{\mathrm{TM}}$ and density centrifugation by Onco-Quick, showed that the CellSearch ${ }^{\mathrm{TM}}$ was a more accurate and sensitive method to detect and enumerate CTCs [32].

In our study, the CTC detection rate among patients with early disease was $37 \%$ and $16.5 \%$ (at $\geq 1$ and $\geq 2$ CTCs) for the CellSearch ${ }^{\mathrm{TM}}$ system, $16.9 \%$ using the IF and $18 \%$ with real time RT-qPCR. Using a highly sensitive and specific real-time RT-PCR method, $20.6 \%$ of 160 patients with early breast cancer had CK-19 mRNA positive cells in peripheral blood [33]. Similarly, in the large prospective SUCCESS trial, $21.5 \%$ of patients with early breast cancer had at least one CTC/23 ml of blood by the use of the CellSearch ${ }^{\mathrm{TM}}$ system [6], although in previous studies, up to $30 \%$ of early breast cancer patients were identified as CTC-positive with the same platform [34,35]. In addition, $20.6 \%$ of 1221 patients enrolled in the SUCCESS trial had at least one CTC detected with manually performed immunocytochemical staining (MICC) using the anti-CK antibody A45-B/B3 on PBMCs [11]. Interestingly, in our study, although the detection frequencies determined by all three methods were comparable, the positive agreement rates were low and the negative agreement rates were modest, resulting in a significant discordance between methods.

In metastatic breast cancer, $53.7 \%$ of patients had $\geq 2$ CTCs per $7.5 \mathrm{ml}$ of blood. Using the same cut-off, Cristofanilli et al. reported that the incidence of CTCs was $64 \%$ among

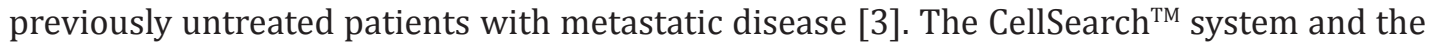
RT-qPCR for CK19 mRNA resulted in comparable detection frequencies in metastatic patients, especially for the cut-off of $\geq 5$ CTCs per $7.5 \mathrm{ml}$. Importantly, in contrast to the early disease setting, a significant concordance between the CellSearch ${ }^{\mathrm{TM}}$ system and the RT-qPCR was evident in metastatic disease. This could be related to the increased CTC load as well as to a more genetically homogenous CTC population in metastatic compared to early disease [36]. 


\section{Cellular Physiology Cell Physiol Biochem 2017;44:594-606 \\ \begin{tabular}{ll|l} 
and Biochemistry & $\begin{array}{l}\text { DOI: 10.1159/000485115 } \\
\text { Published online: November 20, } 2017\end{array}$ & $\begin{array}{l}\text { (c) } 2017 \text { The Author(s). Published by S. Karger AG, Basel } \\
\text { www.karger.com/cpb }\end{array}$ \\
\hline Politaki et al. Comparison of Three Methods for the Detection of CTCs in Breast Cancer
\end{tabular}}

On the other hand, the comparison between the CellSearch ${ }^{\mathrm{TM}}$ system and IF, as well as the RT-qPCR and IF, revealed significant discordance in metastatic patients.

Technical differences in the pre-analytical and analytical procedures employed in each of the detection methods could at least partially explain the observed inconsistency between methods. Indeed, the volume of blood analysed was lower for IF compared to RT-qPCR or the CellSearch $^{\mathrm{TM}}$. Moreover, different CTC isolation techniques were used; automated EpCAMbased immunomagnetic selection was employed for the CellSearch ${ }^{\mathrm{TM}}$ system, whereas, a manually operated density gradient centrifugation was used for RT-qPCR and IF. Finally, different cut-off values defined the positivity for each assay.

Another significant factor, potentially contributing to the discordant results due to the assumed CTC heterogeneity, is that the assays used evaluate different CTC markers. To investigate this hypothesis, triple IF experiments using EpCAM, CK19 and CD45 antibodies were performed on PBMC cytospins from patients presenting discordant results by CellSearch $^{\mathrm{TM}}$ and RT-qPCR. As shown in Table 4, the expression of these markers on CTCs presented inter- as well as intra-patient variability. In addition, in almost two thirds of the patients, the variable expression of these markers could explain the observed disagreement between the CellSearch ${ }^{\mathrm{TM}}$ and RT-qPCR.

The complexity of comparison between different assays regarding CTC prevalence is nicely depicted in the report by Strati et al. evaluating three molecular assays for CTC detection; a singleplex RT-qPCR assay for CK-19, a multiplex RT-qPCR for CK-19, HER-2, MAGE- A3, and PBGD and the AdnaTest Breast Cancer [37]. Importantly, in that study, proanalytical and important analytical variables were kept the same in order to obtain a more precise comparison. When the same target (CK-19) was detected in the same cDNAs with the same set of primers and probes, there was a very good concordance between singleplex RT-qPCR and multiplex RT-qPCR, especially in the metastatic setting. However, discordances between methods were observed when different gene transcripts were used to evaluate CTC positivity, further underscoring the importance of CTC heterogeneity for the detection of CTCs. Interestingly, even when the same target, such as HER2, was detected in the same cDNAs using a different set of primers and different detection systems, the results were not statistically correlated.

Nevertheless, the most important parameter, when comparing different methodologies, is whether they recognize clinically relevant subsets of CTCs. Available evidence suggests that when considering the prognostic significance of CTC detection, the testing method matters. Thus, the CellSearch ${ }^{\mathrm{TM}}$ system was found to be superior compared to AdnaTest in predicting clinical outcome in patients with advanced breast cancer [12]. In the SUCCESS trial [6], the presence of CTCs detected by the CellSearch ${ }^{\mathrm{TM}}$ system was associated with poor patient outcome in early disease, whereas in the same trial, the prognostic relevance of CTCs could not be demonstrated by the use of MICC [11]. These results imply that different CTC detection methods may identify different CTC subpopulations which could be differentially associated with patients' clinical outcome. In our study, the prognostic significance of CTC detection could not be demonstrated in early disease. However, the presence of CTCs determined by any one of the three methods was predictive of reduced overall survival in the metastatic setting.

\section{Conclusion}

The results of this study suggest that the variability regarding the pro-analytical and analytical procedures of the different assays for CTC detection pose a significant limitation in the implementation of CTCs as a tool for patient stratification in clinical trials and/or their use for clinical decision making. Assays and protocols for CTC isolation, detection and characterization need to be well-defined and standardized in detail and have to be validated in prospective clinical trials for correlations with clinical outcome in specific patient populations. 


\section{Cellular Physiology Cell Physiol Biochem 2017;44:594-606 \begin{tabular}{l|l|l} 
and Biochemistry Published online: November 20, 2017 & $\begin{array}{l}\text { (c) } 2017 \text { The Author(s). Published by S. Karger AG, Basel } \\
\text { www.karger.com/cpb }\end{array}$
\end{tabular}

\section{Disclosure Statement}

The authors declare no conflict of interest.

\section{References}

1 Siegel RL, Miller KD, Jemal A: Cancer statistics, 2017 CA Cancer J Clin 2017;67:7-30.

$\longrightarrow 2$ Gerges N, Rak J, Jabado N: New technologies for the detection of circulating tumour cells. Br Med Bull 2010;94:49-64.

3 Cristofanilli M, Budd GT, Ellis MJ, Stopeck A, Matera J, Miller MC, Reuben JM, Doyle GV, Allard WJ, Terstappen LW, Hayes DF: Circulating tumor cells, disease progression, and survival in metastatic breast cancer. N Engl J Med 2004;351:781-791.

- 4 Daskalaki A, Agelaki S, Perraki M, Apostolaki S, Xenidis N, Stathopoulos E, Kontopodis E, Hatzidaki D, Mavroudis D, Georgoulias V: Detection of cytokeratin-19 mRNA-positive cells in the peripheral blood and bone marrow of patients with operable breast cancer. Br J Cancer 2009;101:589-597.

5 Hayes DF, Cristofanilli M, Budd GT, Ellis MJ, Stopeck A, Miller MC, Matera J, Allard WJ, Doyle GV, Terstappen LWWM: Circulating Tumor Cells at Each Follow-up Time Point during Therapy of Metastatic Breast Cancer Patients Predict Progression-Free and Overall Survival. Clin Cancer Res 2006;12:4218.

6 Rack B, Schindlbeck C, Juckstock J, Andergassen U, Hepp P, Zwingers T, Friedl TW, Lorenz R, Tesch H, Fasching PA, Fehm T, Schneeweiss A, Lichtenegger W, Beckmann MW, Friese K, Pantel K, Janni W: Circulating tumor cells predict survival in early average-to-high risk breast cancer patients. J Natl Cancer Inst 2014;106.

7 Xenidis N, Perraki M, Kafousi M, Apostolaki S, Bolonaki I, Stathopoulou A, Kalbakis K, Androulakis N, Kouroussis C, Pallis T, Christophylakis C, Argyraki K, Lianidou ES, Stathopoulos S, Georgoulias V, Mavroudis D: Predictive and prognostic value of peripheral blood cytokeratin-19 mRNA-positive cells detected by realtime polymerase chain reaction in node-negative breast cancer patients. J Clin Oncol 2006;24.

-8 Xenidis N, Ignatiadis M, Apostolaki S, Perraki M, Kalbakis K, Agelaki S, Stathopoulos EN, Chlouverakis G, Lianidou E, Kakolyris S, Georgoulias V, Mavroudis D: Cytokeratin-19 mRNA-positive circulating tumor cells after adjuvant chemotherapy in patients with early breast cancer. J Clin Oncol 2009;27:2177-2184.

-9 Zhang L, Riethdorf S, Wu G, Wang T, Yang K, Peng G, Liu J, Pantel K: Meta-analysis of the prognostic value of circulating tumor cells in breast cancer. Clin Cancer Res 2012;18:5701-5710.

10 Bidard FC, Proudhon C, Pierga JY: Circulating tumor cells in breast cancer. Mol Oncol 2016;10:418-430.

11 Jueckstock J, Rack B, Friedl TWP, Scholz C, Steidl J, Trapp E, Tesch H, Forstbauer H, Lorenz R, Rezai M, Haberle L, Alunni-Fabbroni M, Schneeweiss A, Beckmann MW, Lichtenegger W, Fasching PA, Pantel K, Janni W: Detection of circulating tumor cells using manually performed immunocytochemistry (MICC) does not correlate with outcome in patients with early breast cancer-Results of the German SUCCESS-A- trial. BMC Cancer 2016;16:1-11.

12 Muller V, Riethdorf S, Rack B, Janni W, Fasching PA, Solomayer E, Aktas B, Kasimir-Bauer S, Pantel K, Fehm T, DETECT study group.: Prognostic impact of circulating tumor cells assessed with the Cell Search System and AdnaTest Breast in metastatic breast cancer patients: the DETECT study. Breast Cancer Res 2012;14:R118.

13 Pierga JY, Bonneton C, Vincent-Salomon A, de Cremoux P, Nos C, Blin N, Pouillart P, Thiery JP, Magdelenat H: Clinical Significance of Immunocytochemical Detection of Tumor Cells Using Digital Microscopy in Peripheral Blood and Bone Marrow of Breast Cancer Patients. Clin Cancer Res 2004;10:1392-1400.

14 Heitzer E, Ulz P, Geigl JB: Circulating Tumor DNA as a Liquid Biopsy for Cancer. Clin Chem 2014;61:112-123.

15 Dawson SJ, Tsui DWY, Murtaza M, Biggs H, Rueda OM, Chin SF, Dunning MJ, Gale D, Forshew T, MahlerAraujo B, Rajan S, Humphray S, Becq J, Halsall D, Wallis M, Bentley D, Caldas C, Rosenfeld N: Analysis of Circulating Tumor DNA to Monitor Metastatic Breast Cancer. N Engl J Med 2013;368:1199-1209.

16 Oshiro C, Kagara N, Naoi Y, Shimoda M, Shimomura A, Maruyama N, Shimazu K, Kim SJ, Noguchi S: PIK3CA mutations in serum DNA are predictive of recurrence in primary breast cancer patients. Breast Cancer Research and Treatment 2015;150:299-307.

$>17$ Lianidou ES, Markou A: Circulating tumor cells in breast cancer: detection systems, molecular characterization, and future challenges. Clin Chem 2011;57:1242-1255.

-18 M.Craig Miller, Gerald V.Doyle, Leon W.M.M.Terstappen: Significance of Circulating Tumor Cells Detected by the CellSearch System in Patients with Metastatic Breast Colorectal and Prostate Cancer. J Oncol 2010;2010:617421.

19 Stathopoulou A, Gizi A, Perraki M, Apostolaki S, Malamos N, Mavroudis D, Georgoulias V, Lianidou ES: Realtime quantification of CK-19 mRNA-positive cells in peripheral blood of breast cancer patients using the 


\section{Cellular Physiology Cell Physiol Biochem 2017;44:594-606 \begin{tabular}{l|l|l|l|}
\hline DOI: 10.1159/000485115 & (c)17 The Author(s). Published by S. Karger AG, Basel
\end{tabular} and Biochemistry Published online: November 20, 2017 www.karger.com/cpb}

lightcycler system. Clin Cancer Res 2003;9:5145-5151.

20 Saloustros E, Perraki M, Apostolaki S, Kallergi G, Xyrafas A, Kalbakis K, Agelaki S, Kalykaki A, Georgoulias V, Mavroudis D: Cytokeratin-19 mRNA-positive circulating tumor cells during follow-up of patients with operable breast cancer: prognostic relevance for late relapse. Breast Cancer Res 2011;13:R60.

21 Androulakis N, Agelaki S, Perraki M, Apostolaki S, Bozionelou V, Pallis A, Kalbakis K, Xyrafas A, Mavroudis D, Georgoulias V: Clinical relevance of circulating CK-19mRNA-positive tumour cells before front-line treatment in patients with metastatic breast cancer. Br J Cancer 2012;106:1917-1925.

-22 Kallergi G, Markomanolaki H, Giannoukaraki V, Papadaki MA, Strati A, Lianidou ES, Georgoulias V, Mavroudis D, Agelaki S: Hypoxia-inducible factor-1alpha and vascular endothelial growth factor expression in circulating tumor cells of breast cancer patients. Breast Cancer Res 2009;11:R84.

23 Kallergi G, Konstantinidis G, Markomanolaki H, Papadaki MA, Mavroudis D, Stournaras C, Georgoulias V, Agelaki S: Apoptotic circulating tumor cells in early and metastatic breast cancer patients. Mol Cancer Ther 2013;12:1886-1895.

24 Papadaki MA, Kallergi G, Zafeiriou Z, Manouras L, Theodoropoulos PA, Mavroudis D, Georgoulias V, Agelaki S: Co-expression of putative stemness and epithelial-to-mesenchymal transition markers on single circulating tumour cells from patients with early and metastatic breast cancer. BMC Cancer 2014;14:651.

25 Meng S, Tripathy D, Frenkel EP, Shete S, Naftalis EZ, Huth JF, Beitsch PD, Leitch M, Hoover S, Euhus D, Haley B, Morrison L, Fleming TP, Herlyn D, Terstappen LW, Fehm T, Tucker TF, Lane N, Wang J, Uhr JW: Circulating tumor cells in patients with breast cancer dormancy. Clin Cancer Res 2004;10:8152-8162.

26 Kallergi G, Papadaki MA, Politaki E, Mavroudis D, Georgoulias V, Agelaki S: Epithelial to mesenchymal transition markers expressed in circulating tumour cells of early and metastatic breast cancer patients. Breast Cancer Res 2011;13:R59.

-27 Theodoropoulos PA, Polioudaki H, Agelaki S, Kallergi G, Saridaki Z, Mavroudis D, Georgoulias V: Circulating tumor cells with a putative stem cell phenotype in peripheral blood of patients with breast cancer. Cancer Lett 2010;288:99-106.

28 Yu M, Bardia A, Wittner BS, Stott SL, Smas ME, Ting DT, Isakoff SJ, Ciciliano JC, Wells MN, Shah AM, Concannon KF, Donaldson MC, Sequist LV, Brachtel E, Sgroi D, Baselga J, Ramaswamy S, Toner M, Haber DA, Maheswaran S: Circulating breast tumor cells exhibit dynamic changes in epithelial and mesenchymal composition. Science 2013;339:580-584.

-29 Demeulemeester J, Kumar P, Müller EK, Nord S, Wedge DC, Peterson A, Mathiesen RR, Fjelldal R, Zamani Esteki M, Theunis K, Fernandez Gallardo E, Grundstad AJ, Borgen E, Baumbusch LO, Borresen-Dale AL, White KP, Kristensen VN, Van Loo P, Voet T, Naume Br: Tracing the origin of disseminated tumor cells in breast cancer using single-cell sequencing. Genome Biology 2016;17:250.

-30 Andreopoulou E, Yang LY, Rangel KM, Reuben JM, Hsu L, Krishnamurthy S, Valero V, Fritsche HA, Cristofanilli M: Comparison of assay methods for detection of circulating tumor cells in metastatic breast cancer: AdnaGen AdnaTest BreastCancer Select/Detect versus Veridex CellSearch system. Int J Cancer 2012;130:1590-1597.

-31 Van der Auwera I, Peeters D, Benoy IH, Elst HJ, Van Laere SJ, Prove A, Maes H, Huget P, van Dam P, Vermeulen PB, Dirix LY: Circulating tumour cell detection: a direct comparison between the CellSearch System, the AdnaTest and CK-19/mammaglobin RT-PCR in patients with metastatic breast cancer. Br J Cancer 2009;102:276-284.

32 Balic M, Dandachi N, Hofmann G, Samonigg H, Loibner H, Obwaller A, van der Kooi A, Tibbe AG, Doyle GV, Terstappen LW, Bauernhofer T: Comparison of two methods for enumerating circulating tumor cells in carcinoma patients. Cytometry B Clin Cytom 2005;68:25-30.

-33 Stathopoulou A, Ntoulia M, Perraki M, Apostolaki S, Mavroudis D, Malamos N, Georgoulias V, Lianidou ES: A highly specific real-time RT-PCR method for the quantitative determination of CK-19 mRNA positive cells in peripheral blood of patients with operable breast cancer. Int J Cancer 2006;119:1654-1659.

34 Biggers B, Knox S, Grant M, Kuhn J, Nemunatitis J, Fisher T, Lamont J: Circulating Tumor Cells in Patients Undergoing Surgery for Primary Breast Cancer: Preliminary Results of a Pilot Study. Ann Surg Oncol 2009;16:969-971.

-35 Sandri MT, Zorzino L, Cassatella MC, Bassi F, Luini A, Casadio C, Botteri E, Rotmensz N, Adamoli L, Nole F: Changes in Circulating Tumor Cell Detection in Patients with Localized Breast Cancer Before and After Surgery. Ann Surg Oncol 2010;17:1539-1545.

-36 Klein CA: Selection and adaptation during metastatic cancer progression. Nature 2013;501:365-372.

-37 Strati A, Kasimir-Bauer S, Markou A, Parisi C, Lianidou ES: Comparison of three molecular assays for the detection and molecular characterization of circulating tumor cells in breast cancer. Breast Cancer Res 2013;15:R20. 